\title{
Constitutional Provisions for Right to Education in the Indo-Nepalese Context: Gap between Policy and Practice
}

\author{
Digvijay Singh Pathani ${ }^{1} \&$ Madan Singh Deupa ${ }^{2, *}$ \\ ${ }^{1}$ Department of Political Science, DSB Campus, Kumaun University, India \\ ${ }^{2}$ Department of Education, University Central Campus, Far Western University, Nepal \\ *Corresponding author: Department of Education, University Central Campus, Far Western \\ University, Nepal. Tel: 977-984-888-1262. E-mail: madandeupa14@gmail.com
}

Received: November 19, 2021 Accepted: January 5, 2022 Published: March 6, 2022

doi:10.5296/ije.v14i1.19626 URL: https://doi.org/10.5296/ije.v14i1.19626

\begin{abstract}
This study aims at comparatively identifying the constitutional provisions for right to education, their implementation and impact on education in India and Nepal. This is an analytical descriptive study based on document analysis. By the mid of $2011,81 \%$ constitutions of the world guaranteed or aspired to protect the right to primary education. Nepal and India both have clear constitutional provisions for right to free and compulsory basic education but are unable to fulfil the international and national educational commitments and goals. India and Nepal fall in 2nd and 48th rank respectively based on population in the world in 2018. However, educational indicators indicate that both the countries could not ensure the educational access to all the children. In the year 2014-15, 22.131 million children were either not enrolled or did not complete primary education in India. This number was 270958 in Nepal in the same year. Results show that there is a wide gap between the educational policies and their actual implementation in India and Nepal.
\end{abstract}

Keywords: constitutional provision, right to education, educational policy, educational access, literacy 


\section{Introduction}

During the development of human civilization, so many factors like geographical territory, nature and development of society, unequal access and impartation of education, development of consciousness, economic, trade and commercial activities, unequal distribution of natural resources and capital, culture, race, gender, color, religion, caste etc. created significant inequality among human beings. Gradually, voices were raised against all kinds of discrimination and the concept of human rights was evolved globally. One of these human rights is Right to Education.

Purpose of this paper is to identify the constitutional provisions of right to education and their implementation in India and Nepal. This study also intended to find the present situation of educational access, enrollment, out-of-school children and literacy rates in Indo-Nepalese contexts and hence compare them. Well defined educational system was developed by Sparta according to its military, social and economic purposes on 500 B.C. (Xenophon, The Lacedemonian constitution, Ch. II cited in UNESCO, 1968, p.23). Continuation on planning of education was made by Han dynasties of China, Icas of Peru and some of other civilizations. Historical background of the right to education is directly related to the planning of education. In 1913, around $67 \%$ of the population of the USSR was illiterate while the first attempt for systematic educational planning was made on 1923 (UNESCO, 1968, p.23).

After Second World War, UNO was established in October 24, 1945 and Universal Declaration of Human Rights took place in December 10, 1948 stating its Article 1; "All human beings are born free and equal in dignity and rights. They are endowed with reason and conscience and should act towards one another in a spirit of brotherhood" (UNO, 1948, p.4). In the same document, right to education is quoted in Article 26; "(1) Everyone has the right to education. Education shall be free, at least in the elementary and fundamental stages ......... (2) Education shall be directed to the full development of the human personality ........ (3) Parents have a prior right to choose the kind of education that shall be given to their children" (p.54).

Results of the Second World War made so many countries plan their educational systems. All 146 local boards of education of United Kingdom developed their plans according to the education act of 1944. Education was not included in first plan (1946) of France but it included in their national plan in 1953 after recommendation of a commission in 1951. After the downfall of colonization, many of the countries became independent in the decade of fifties and onwards and focused to educational development. India included education in their first plan in 1951 while Ghana launched an eight-year general development plan in the same year including education (UNESCO, 1968, pp.23-24). Nepal launched its first five-year national plan in 1956. Although the expenditure was only NCR 210 million it made significant progress in education and health, road, power and industrial development (NPC, 2017). Burma, Columbia, Morocco, Pakistan, and Tunisia addressed the education in their first plan launched in 1952, 1957, 1958, and 1959 respectively (UNESCO, 1968, p.24).

Besides UDHR, child rights were declared on 20th November 1959 realizing that," Whereas the child, by reason of his physical and mental immaturity, needs special safeguards and care, 
including appropriate legal protection, before as well as after birth". Declaration of the rights of the child (1959) mentioned in its Principle 5 that " The child who is physically, mentally, or socially handicapped shall be given the special treatment, education and care required by his particular condition. In Principle 7; right to education is addressed as, "The child is entitled to receive education, which shall be free and compulsory, at least in the elementary stages" (UN, 1959, pp.1-2).

Child right convention held on 1989 secured the rights of the child related to education in article 28(1) as," States parties recognize the right of the child to education, and with a view to achieving this right progressively and on the basis of equal opportunity, they shall, in particular: make primary education compulsory and available free to all; encourage the development of different forms of secondary education; make higher education accessible to all on the basis of capacity; make educational and vocational information guidance available and accessible to all children; take measures to encourage regular attendance at schools and reduction of dropout rates" (UN, 1989, p.8).

UNESCO (2007) mentioned in its report, A Human Right Based Approach to Education that the legislation must ensure the entitlement of all children to compulsory primary education. This provision is provided in constitution of some of the countries. In India, children between 6 to 14 years are provided free and compulsory education through 93rd constitutional amendment while 25 of the countries had not mentioned specific age of the children for primary education by 2004. At the time of UDHR, the concept of fundamental education was popularly used in international context but it has become obsolete today (UNESCO, 2000, p.26).

Continuing the journey for right to education, another important effort made by international context was Jomtien conference held on 9 March 1990. This conference declared Education for All by revealing the facts that, "More than 100 million children, including at least 60 million girls have no access to primary schooling; more than 960 million adults, two-third of who are women, are illiterate; more than one-third of the world's adults have no access to the printed knowledge; more than 100 million children and countless adults fail to complete basic education"(World Declaration on Education for All, 1990, p.1).

To make the easy access to education, so many regional conferences were held based on education. On the decade of sixties, three important conferences on education were held in Asia region. The Karachi Conference (December 1959-January 1960) recommended for free and compulsory primary education of at least 7 years duration within a maximum period of 20 years (1960-1980). The main objectives of Tokyo Conference (April 1962) was to review the" Karachi Plan" and reports submitted on the development of primary education. Similarly, the Bangkok Conference (November 1965) carried on the work performed at Karachi and Tokyo and adopted a draft "Model for Educational Development" for Asia for the Period 1965-1980 (UNESCO, 1968, p.25). Right to education was also recognized by International Human Rights Conventions as the succession of UN Conventions from 1948 to the Convention on the Rights of the Child (1989) mentioning that making education compulsory and free is the responsibility of the governments (UNESCO Institute for Statics, 2005, p.11). 
The Universal Declaration of Human Rights (UDHR, UN General Assembly, 1948) guarantees the right to education and specifies that schooling should be free and compulsory at the primary level. Following the same, commitment was made by 193 state parties through Convention on the Rights of the Child (CRC) to provide free and compulsory primary education and make secondary education accessible to every child. These commitments led the results that by the June of $2011,81 \%$ of constitutions secured or aspired to protect the right to primary education, $43 \%$ of countries guaranteed free and compulsory primary education, $10 \%$ of constitutions guaranteed free primary education but didn't make it compulsory, $6 \%$ made primary education compulsory but not free, $14 \%$ guaranteed without mentioning whether it was free or compulsory and 7\% of countries mentioned the right to primary education as an aspiration (Heymann, Raub, and Cassola, 2014, pp.132-135).

Almost seven decades of declaration of universal human rights, six decades of Karachi conference and three decades of Jomtien conference have passed by but so many reports show that most of the nations are unable to achieve the goals set by above-mentioned educational conferences. Despite these efforts, a significant number of children/people is out of school. Two-third of countries was unable to meet all of the EFA goals. Fifty percent of countries achieved universal primary enrollment. There were 204 million children and adolescents out of school in 199 which reduced to 127 million in 2008 and in 2012 it was 121 million (Dahal, 2015, p.2). UNESCO statistics on enrollment indicates that 77 million children in 2004 were not enrolled in school while UNICEF sources indicate that this figure may be as many as 90 million children for 2005-2006 in terms of school attendance (UNESCO, 2007, p.1). Across the globe, 10.6\% youths are lacking basic numerical and reading skills being illiterate. In developing countries, this percent was 12.1 with Sub-Saharan Africa's 19.6 and in South and West Asia 19.6 percent (Government of India, 2017, pp.4-5).

In 2001-02, there were 162 million out-of-school children in Asia (36\% of the world's out-of-school children) out of which 42 million (26\%) were from South Asia, which is the highest absolute number in the region. Results revealed that one fourth of the school age children were out of school in the above-mentioned period. Despite significant efforts, position of South Asia in out-of-school children (primary and lower secondary) is second in the world. UNESCO Institute for Statistics (UIS) highlighted the fact that in 2012, 9.8 million children in primary and 26.4 million children in lower secondary school age had no access to school education in this region (MoE, UNICEF and UNESCO, 2016, p.1)

Pakistan and Nepal hold the first and the second position with $40 \%$ and $34 \%$ in out-of-school children. Number of out-of-school children in India is approximately 27 million $(23 \%$ of out-of-school children of the world) which is the highest absolute number of out-of-school children in the world. One out of four children in India was not attending the school. This number in Bangladesh was 3.7 million (one out of five). Number of out-of-school children in Sri Lanka and the Maldives is comparatively less (below 5\%) in South Asia (UNESCO Institute for Statics, 2005, p.21). In these contexts, it is relevant to identify the present status of educational access, provisions of right to education and their implementation, and number of out-of-school children in India and Nepal. 


\section{Methodology}

The information collected for this study was qualitative as well as quantitative. Hence the research design adopted was mixed in nature. This study was based on document analysis. To collect the required data, national and international documents on educational conferences, constitutional provisions for free and compulsory education and current position of educational access were analyzed, and a comprehensive study was made on contemporary literature. Statistical procedures and descriptive method were used to interpret and analyze the result.

\section{Results and Discussions}

\subsection{Constitutional Provisions for Right to Education in India}

Today, India's education system is taken as the second largest in the world after China. Historically, Indian education has been elitist especially for Brahmins; the highest caste group in India. India's education policies enhanced the pre-existing elitist tendencies under British rule from 1700s to 1947 (Cheney, 2005, p.2). Enactment of the Compulsory Education Act in 1870 in England (Mondal, 2017, p.1) raised the voice for free and compulsory education in India (Juneja, 2003, p.15).

To fulfill the international and national commitments related to free and easy access to education, most of the countries made the constitutional provisions for right to education. United States of America made its constitution in 1787 and ratified in 1789 which was the shortest constitution in the modern history of constitution (Dahal, 2017, p.150). In Indian constitution, adopted by the Constituent Assembly in November, 1949, Article 45 stated that: "The state shall endeavor to provide, within a period of ten years from the commencement of this constitution for free and compulsory education for all children until they complete the age of fourteen years". In the same constitution, Article 41 mandated the state to make provision for securing the right to education "within the limits of its economic capacity and development" (Ministry of Human Resource Development, 2016, p.17).

In Indian constitution, initially education was defined as State subject. But an amendment was made under Article 42 of the constitution in 1976 which made education a concurrent list subject and the central government had right to legislate it in the manner suited to it. India is also a signatory to number of international covenants i.e., UDHR, DRC, EFA, UNCRC, MDGs, Dakar declaration, SAARC SDG and hence committed to make easy access to education for all children (National Coalition for Education and World Vision India, 2012 p.1).

The act made by 86th amendment of Indian constitution (Article 21A, Part III- Fundamental Rights) addresses education as a fundamental right to children of the age group of 6 to 14 years by stating that, "The State shall provide free and compulsory education to all children of the age of six to fourteen years in such manner as the state may, by law, determine" (The Constitution of India, 1949, p.11). Before the insertion of Article 21A, right to education was 
related to article 21 (which was on right to life) by the Supreme Court of India held in 1992 (Ahmad, 2016, p.21).

The 86th constitutional amendment making education a fundamental right was passed by Parliament in 2002. This act received the assent of the president on the 26th August, 2009 and was published for general information on 27 August, 2009. This amendment and a new law The Right of Children to Free and Compulsory Education Act came into force from 1st April 2010.

The bill related to this act was introduced in the Rajya Sabha, the upper house of Indian parliament on 2008, as Bill No. LXV of 2008, known as The Right of Children to Free and Compulsory Education Bill, 2008 (MHRD, 2008). This bill contains total seven chapters and 37 sections. But one more section was added to the RTE Act-2009 in chapter-VI as "Constitution of State Advisory Board". This act is known as Right to Education Act-2009 (Gazette of India Extraordinary, 2009). The provisions of this act can be concluded as below:

"The 86th Amendment of the Constitution in December 2002 and its enactment since 1st April 2010 has makes free and compulsory education for all children in the 6-14 age groups a justifiable fundamental right. The Act makes it a right of every child to get education. The Act makes it obligatory for the appropriate governments to ensure that every child gets free elementary education. The Act mandates that even private educational institutions have to reserve 25 per cent seats for children from weaker sections. As per the government's estimate, there will be a requirement of Rs 1.71 lakh crore in the next five years for implementation of the Act. The Act says no school can deny admission to a student and all schools need to have trained teachers. In case of schools not having trained teachers, they will have to comply with the provision within three years. As per the new law, the schools need to have certain minimum facilities like adequate teachers, playground and infrastructure. The government will evolve some mechanism to help marginalized schools comply with the provisions of the Act. The government has already prepared model rules which have been circulated to the states for preparing their own rules for implementation of the Act. The Centre has also prepared separate rules for the Union Territories which will be notified by the Law Ministry next week. However, the reservation for weaker section will not be implemented from this year as the admission season is almost over. It will be implemented from 2011-12. The state government and local authorities will establish primary schools within walking distance of one $\mathrm{km}$ of the neighborhood. In case of children for Class VI to VIII, the school should be within a walking distance of three $\mathrm{km}$ of the neighborhood (National Coalition for Education and World Vision India, 2012, p.2).”

Besides these constitutional provisions for right to education in India, there were other important efforts also made to make the access to education easy and increase the literacy rate. To universalize the elementary education, Sarva Shiksha Abhiyan (SSA) programme was started since 2000-2001. The Rashtriya Madhyamic Shiksha Abhiyan (RMSA) was launched in 2009 to make easy access to secondary education by removing all kinds of discrimination, and a centrally sponsored scheme Rashtriya Uchchatar Shiksha Abhiyan (RUSA) was introduced in 2013 to consolidate higher education. In 2000, United Nations 
adopted Millennium Development Goals (MDGs) and India too committed to these goals (Ministry of Human Resource Development, 2016, p.23).

Voice for free education was raised in pre-independent India almost 150 years ago under British Rule and after independence, India has made a significant effort to make constitutional provisions for right to education. Initially, Indian constitution defined education as state subject and Article 41 and 45 mentioned that the state shall try to provide free and compulsory education to all children until they complete the age of fourteen years. After making the education a concurrent list subject in 1976 by amending the Article 42, the Article 21A was inserted in the constitution in 2002 and education was made fundamental right. Currently, India is providing free and compulsory education to all the children between 6-14 years. But level of free and compulsory education is not mentioned in this act. India has been participating in all the international conferences/conventions on education and has been making commitments for the same. In past two decades, India also launched so many programs like SSA, RMSA and RUSA to expand and make easy access to education.

\subsection{Constitutional Provisions of Right to Education in Nepal}

Nepal is an ancient country and historical evidences show that the formal ruling was started in Nepal since 1000 BC by Gopal dynasty. But constitutional history of Nepal seems to have started from 5th decade of 20th century after formulation of The Government of Nepal Act-1948 (2004 Bikram Samvat, BS) by the then Rana rulers (Timalsina and Shreshtha, 2015, p.11). There were other constitutions also constructed in Nepal like The Interim Government of Nepal Act, 1951 (Nepal Antarim Shasan Vidhan, 2007 BS); The Constitution of the Kingdom of Nepal, 1959 (Nepal Adhirajya Ko Samvidhan, 2015 BS); The Constitution of Nepal, 1962 (Nepal Ko Samvidhan, 2019 BS), The Constitution of the Kingdom of Nepal, 1990 (Nepal Adhirajya Ko Samvidhan, 2047 BS) (Dahal, 2001); Interim Constitution of Nepal 2006 (2063 BS) and The Constitution of Nepal 2015 (2072 BS).

In Nepal, firstly constitutional provision for right to education was made by first constitution of Nepal, Government of Nepal Act-1948 (Bhandari, 2014, p.1). This constitution made a constitutional provision for universal free compulsory elementary education throughout the country in section-4 (Government of Nepal Act, 1948, p.2) but this Act was not implemented. There was no any provision for right to education in the second constitution of Nepal, The Interim Government of Nepal Act, 1951. The third constitution of Nepal, The Constitution of the Kingdom of Nepal, 1959 had six fundamental rights in part III but right to education was not included in this constitution too. Similarly, seven fundamental rights were mentioned in part 3 of fourth constitution of Nepal, The Constitution of Nepal, 1962 excluding right to education (Dahal, 2001).

After the reestablishment of democracy by people's movement in 1990, fifth constitution of Nepal was constructed as The Constitution of the Kingdom of Nepal, 1990. In this constitution, cultural and educational right was expressed in Article 18 of part 3 (Fundamental Rights) as: "(1) Each community residing within the Kingdom of Nepal shall have the right to preserve and promote its language, script and culture. (2) Each community shall have the right to operate schools up to the primary level in its own mother tongue for 
imparting education to its children" (Constitution of the Kingdom of Nepal, 1990, p.24). Nepal made a historical political change and provisions for state restructure in 2007 through sixth constitution, The Interim Constitution of Nepal, 2007. This constitution had 21 fundamental rights and the right to education was secured by Article 17 (Education and Cultural Rights) of part 3 (Fundamental Rights) as: "(1) Each community shall have the right to receive basic education in their mother tongue as provided for in the law. (2) Every citizen shall have the right to receive free education from the state up to secondary level as provided for in the law. (3) Each community residing in Nepal has the right to preserve and promote its language, script, culture, cultural civilization and heritage." (The Interim Constitution of Nepal, 2007, p.8).

Now Nepal is a Federal Democratic Republic State and has a seventh constitution as Nepal's Constitution of 2015. In part 3 (Fundamental Rights and Duties), 31 fundamental rights are mentioned out of which right to education is reserved in Article 31 (Right to Education) as: "(1) Every citizen shall have the right to access to basic education. (2) Every citizen shall have the right to compulsory and free basic education, and free education up to the secondary level. (3) The physically impaired and the citizens who are financially poor shall have the right to free higher education as provided for in law. (4) The visually impaired person shall have the right to free education with the medium of brail script. (5) Every Nepali community living in Nepal shall have the right to acquire education in its mother tongue up to the secondary level, and the right to open and run schools and educational institutions as provided for by law." Article 39 (2) also ensures again right to education of the children (Right of Children) (Nepal's Constitution of 2015 with Amendments through 2016, pp.21-22). To implement the right to education provided by Nepal's Constitution of 2015, Education Act, 1971(Act No. 8 of the Year 1971) was amended on June 29, 2016 as eighth amendment. Right to education is mentioned in Section 16(D) and provision for not to expel the children from school and give physical and mental torture is in Section 16(M).

Concept of free and compulsory education was practiced in Nepal even before 1951. The first Education Ordinance of 1939 (BS 1996 Saal Ko Shiksha Ishtihaar) had the provision of fee waiving for selected few poor children (Parajuli and Acharya, 2014, p.80). Durbar School established in 1853 is taken as first formal school in Nepal which was intended to serve children from elite families (G. C. and Shrestha, 2014, p.192), and systematic effort for public education was begun after the formation of Nepal National Educational Planning Commission (NNEPC) in 1953. Announcement for free education (grade 1-3) was made in 1975. Primary education was upgraded to grade 5 in 1980 and became free with free text books. Again, continuing the effort, lower secondary level (grade 1-8) was made free with free text books in 2008. Provision for free education and text books was extended to grade 12 for deprived group and Karnali region (Parajuli and Acharya, 2014, p.81).

Development plans of Nepal also emphasized the easy and universal access to education. The first educational development plan (1956-1961) advocated for universal primary education until 1985. The Third Developmental Plan (1965-70) provided support for free and compulsory education. Jhapa and Chitawan districts were provided support for free and compulsory education by Fourth Plan (1970-75). Fifth and Sixth plans were silent on this 
matter. Again, seventh plan (1985-90) had provisions for compulsory primary education on the basis of efforts of municipality. The Eighth (1992-97), Ninth (1997-2002) and Tenth (2002-07) Development Plans also mentioned the matter of free and/or compulsory education in some extent and forms. Free and compulsory education to basic level was also supported by the Three Year Interim Plan (2007-10) (Parajuli and Acharya, 2014, p.81). Now Fourteenth Plan (2016-19) is being implemented in Nepal and lifelong education, compulsory basic education and free basic and secondary education is significantly emphasized by this plan (Government of Nepal, 2016, p.132).

Nepal also made significant efforts for right to education during past 65 years. Nepal had seven constitutions made from the period of Rana regime (1948) to Constitution Assembly (2015). Most of the constitutions had their provisions for right to education. Currently there is a clear provision for right to free and compulsory basic education (grade 1 to 8 ) and free secondary education (grade 9 to 12) in the constitution of Nepal 2015. Free books are also provided to all children of basic education. Free and easy access to education is also emphasized by most of the Development Plans and educational commissions of Nepal.

\subsection{Present Status of Educational access in India}

\subsubsection{Population}

India is the second highest populous country in the world after China. Merely $2.4 \%$ of the total land of the world is occupied by India while approximately $17 \%$ of the population of the world resides here. Population of India in first Census 1901 was 238396327 and this figure reached 1210193422 in 2011 (Demographic Trends of India, n. d., pp.60-65). India's population was estimated as 1,314 million in 2015 (Population Education and Health Research Center (P) Ltd., 2016, p.12); 1328.9 million in 2016 (Population Reference Bureau, 2016, p.13) and 1339.18 million in 2017 (World Development Indicators database, World Bank, 2018, p.1). According to the estimation of United Nations, Department of Economics and Social Affairs, Population Division (2017), population of India will be 1359.57 million in 2018; 1512.98 million in 2030 and 1658.97 million in 2050. In the same estimation it is found that the population of China will be 1417.09 million in 2018; 1441.18 million in 2030 and 1364.45 million in 2050. This data indicates that the population is rapidly increasing in India. In 2018, India is succeeding China by 57.52 million people but in 2030 India will precede China by 71.80 million people being the largest populous country in the world. In 2014, the estimated population for age group 6-10 years (primary level, up to grade 5) was 130648000 and the population was 254862000 for age group 6-15 years (secondary level, up to grade 10) in the same year in India (Government of India, 2016, p.1).

\subsubsection{Enrollment}

To fulfill the national and international commitments on right to education, India is making significant efforts from the decades of seventies to date. Enrollment in primary education in 2000-01 was 113.8 million while it increased to 132.1 million in the year 2005-06. Similarly, the numbers of enrollment were 135.3 million and 132.4 million in the years 2010-11 and 2013-14 respectively (Government of India, 2014, p.24). Again, the number of enrollment in 
the same level in the year 2014-15 was 130.501 million (Government of India, 2016, p.4).

\subsubsection{GER and NER}

Gross Enrollment Rate (GER) and Net Enrollment Rate (NER) are educational indicators used to indicate the enrollment of particular year. GER denote total enrollment percent of children of any age in particular grade/level with reference to the number of children of specified age group for that grade/level while NER stands for the enrolment percent of children of specified age group for any particular grade/level. In India, GER in primary education in the year 2000-01 was $95.7 \%$ and this rate was $109.4 \%, 116.0 \%$ and $101.4 \%$ for the years 2005-06, 2010-11 and 2013-14 respectively (Government of India, 2014, p.26). This rate was 100.1\% in 2014-15 (Government of India, 2016, p.7). NER in the primary level was $84.5 \%$ in the year 2005-06, increased to $88.08 \%$ in 2013-14 (Government of India, 2014, p.28) and again decreased to $87.4 \%$ in 2014-15 (Ministry of Human Resource Development, 2016, p.25).

\subsubsection{Dropouts and Literacy Rate}

India's literacy rate at the time of independence was 12\% (Ministry of Human Resource Development, 2016, p.2). These rates were gradually increased to $18.3 \%, 28.3 \%, 34.5 \%$, $43.6 \%, 52.2 \%, 64.8 \%$ and $73 \%$ in the years 1951, 1961, 1971, 1981, 1991, 2001 and 2011 respectively (Government of India, 2016, p.17). Kerala has the highest literacy rate $93.91 \%$ while Bihar is the least literate state with literacy rate $63.82 \%$ (Ministry of Human Resource Development, 2016, p.24). Presently, in India, literacy has been defined as the understanding of reading and writing in any language by the person of age seven and above (Government of India, 2016, p. $A_{1}$ ). Though significant progress has been made by India during past few years, still there are so many problems in the field of education (Government of India, 2014, p.3).

Dropout is another factor, which creates obstacle to meet the goal of education for all. Dropouts are those, who are unable to complete the particular grade or level. Number of dropouts is found by using the following relationship:

Gross dropout rates for classes $1-5=\{1$-(Enrollment in class 5 during the reference year $\div$ the enrollment in class 1 four years ago) $\} \times 100$.

In India, in primary education, dropout rate in the year 2000-01 was $40.7 \%$ which decreased to $29 \%$ in $2004-05,25.7 \%$ in $2005-06$ and $24.9 \%$ in $2008-09$. These rates were declined to $9.1 \%$ in the year 2009-10, 4.7\% in 2012-13 (Government of India, 2014, pp.46-48) and 4.34\% in 2013-14 (Government of India, 2016, p.7).

Another scenario of educational access can be analyzed by number of out-of-school children. In the year 2001-02, total primary level school age population of India was 648.545 million out of which 115.375 million (17.8\%) children were out of school (UNESCO Institute for Statistics, 2005, p.18). For the total population in the age group 6-14 years, the number of out-of-school children was 13.45 million $(6.94 \%)$ in the year 2005-06 and 8.15 million (4.28\%) in 2009-10 (Government of India, 2014, p.44). 
3.4 Present Status of Educational access in Nepal

\subsubsection{Population}

Nepal has the history of census since 1911. First census showed the population of Nepal as 5 638749 (Sharma, n. d., p.1) which grew up to 26494504 in 2011 (Government of Nepal, 2014, p.19). Population of Nepal met the figure 28.0 million in 2015 (Population Education and Health Research Center (P) Ltd., 2016, p. 12); 28.4 million in 2016 (Population Reference Bureau, 2016, p.13) and 29.3 million in 2017 (World Development Indicators database, World Bank, 2018, p.1). In 2018, Nepal ranks 48 occupying 0.39\% population of the world. Estimation shows that population of Nepal will be 29.74 million in $2018 ; 33.16$ million in 2030 and 36.10 million in 2050 (United Nations, Department of Economics and Social Affairs, Population Division, 2017). In the year 2011, total population of the age group 5-9 years (primary level) was 3204859 and for the age group 10-12 years was 2169404 (MoE, UNICEF, UNESCO, 2016, p.125).

\subsubsection{Enrollment}

In Nepal, only $77(0.9 \%)$ children were enrolled in primary education in 1951 . This number increased to $20940(15.8 \%)$ in 1961 and 143725 (32\%) in the year 1970 (National Education System Plan for 1971-1976, 1971, p.15). Enrollment rate was 62\% in 1990 (National Education Commission, 1992, p.12). Likewise, the number of students enrolled in primary education was 2,884,275 in 1991 (GC and Shrestha, 2014, p.195); 3091684 in the year 1993; 3191614 in 1994; 3263050 in 1995; 3447607 in 1996 and 3460756 in the year 1997 (Tuladhar, 2004, p.120). This number was increased to 3853000 in 2001 (GC and Shrestha, 2014, p.195); 4502697 in 2005; 4515059 in 2006; 4418713 in 2007; 4782313 in 2008; 4 900663 in 2009; 4951956 in 2010 and 4782885 in the year 2011 (Devkota and Bagale, 2015, p.156). Again, enrollment of children in primary education was decreased to 4335355 in the year 2014-15 (Ministry of Education, 2015 a, p.6).

\subsubsection{GER and NER}

GER was $86 \%$ in the year 1995-96 and $112 \%$ in 2003-04 and NER for the same years were $57 \%$ and $72 \%$ (GC and Shrestha, 2014, p.197). GER and NER in primary level in the year 2004 were 131\% and 84\% (Mathema, 2007, p.47). GER was 121\% in 2011 (GC and Shrestha, 2014, p.197) while NER was 95.1\% in 2011 (Wagle, 2012, p.16) and 96\% in 2015 (MoE, UNICEF and UNESCO, 2016, p.vi). Flash I (2014-15) pointed out that GER and NER for primary level were 134.4\% and 96.2\% respectively (Ministry of Education, 2015 a, p.10). According to the report of Education for All National Review (2001-2015), GER of primary education in the years 2000-01, 2006, 2010-11 and 2012 were 124.7, 138.8, 121 and 130.1. Similarly, NER for the years 2001, 2006, 2012 and 2014-15 are listed as 81.1, 87.4, 95.3 and 96.2 (Ministry of Education, 2015 b, p.12).

\subsubsection{Dropouts and Literacy Rate}

In Nepal, Rana rule was overthrown and democracy was established in 1951. Educational scenario of that time revealed that the enrollment in primary and secondary schools was 9 
000 and 1700 respectively. There was no university and two undergraduate colleges with around 100 students. Adult literacy was barely at 5\% (Mathema, 2007, p.46). Literacy rates in the years 1971, 1981 and 1991 were $13.9 \%, 23.3 \%$ and $39.6 \%$ respectively (GC and Shrestha, 2014, p.202). This rate was increased to $53.74 \%$ in 2001 and $65.94 \%$ in 2011 (Ministry of Education, 2015 a, p.3).

Census 2011 highlighted the fact that 0.57 million primary school age and 0.20 million lower secondary school age children out of total 5.2 million (aged 5-12 years) children were out of school in Nepal (MoE, UNICEF, UNESCO, 2016, p.VIII). The Nepal Living Standard Survey (NLSS)-III (CBS, 2011) report flashed that 7.8 million (32.6\%) population out of 23.9 million population aged five years and above had no any kind of education. According to census 2011, total number of illiterate population (5 years and above) was 8.127 million (GC and Shrestha, 2014, p.200). The Global Monitoring Report 2013/14 (UNESCO, 2013) indicated that in 2015, 7.5 million people in Nepal were illiterate and around one million children added to this figure every year (Dahal, 2015, p.11).

Nepal government's Flash Report (2011-12) indicated that the percentage of dropout in lower secondary and secondary level was 6.5\% and 6.9\% respectively (Wagle, 2012, p.16). Dropout of primary education in Nepal on 2011/12 (Flash report) was 5.4\% and it was decreased to $5.2 \%$ in $2012 / 13$. Repetition rate was 10.6 and promotion rate was 84.2 . Every year $4.8 \%$ of students are leaving schools (Devkota and Bagale, 2015, pp.153-156). Flash-I report of 2014/15 showed the dropout rate as 4.2 in primary education (Ministry of Education, 2015, p.12).

According to Agency for Development and Cooperation and Alliance (2006), only around 18\% complete the primary education in 5 years and only $8 \%$ pass the School Leaving Certificate Examination (Mathema, 2007, p.53). Census 2011 revealed that around 14.3\% of children (17.9\% of primary and $9 \%$ of lower secondary school age group) were not attending school. Again according to Multiple Indicator Cluster Survey (MICS, 2014), 16.1\% children (23.2\% of primary and 5\% of lower secondary school age) were out of school in 2014 (MoE, UNICEF, UNESCO, 2016, p.18).

\subsection{Comparison between India and Nepal}

\subsubsection{Constitutional Provisions for Right to Education}

In India, first voice for free and compulsory education was raised in 1870 during British rule. After being independent in 1947, India made its constitution in 1949 and responsibility of education was given to states. Clear provisions for free and compulsory education were made by 86th amendment of the Indian constitution by making the constitution Act, 2002 which was finally came into force from 2010 . According to this constitutional provision, all children of India of the age group of 6 to 14 years should be provided free and compulsory education. Level of the education that provided to children is not mentioned in this Act but practice of age groups for different levels (age group 6-11 years for grades 1-5 and age group 11-14 years for grades 6-8) in Indian school education system indicates that free and compulsory education will be provided up to grade 8 (up to upper primary level). 
On the other side, Nepal is a country that never became slave or colonized country and free from its existence. But formal constitution was constructed only in 1948 under Rana regime. After it, constitutions were constructed on every political fluctuations and seventh constitution was constructed by Constitutional Assembly in 2015. Provisions for free and compulsory primary education were made by the first constitution of Nepal in 1948 but it was not implemented. Although concept of right to education was mentioned in other constitutions and educational committees/commissions of Nepal however clear provision for right to education was made by constitution of Nepal 2015. This constitution secures the right to compulsory and free basic education (up to grade 8) and free education up to the secondary level (grade 9-12). Age group for basic free and compulsory education is not specified like in Indian constitution.

\subsubsection{Present Status of Educational Access}

In present, India is the second most populous country in the world and its population growth rate indicates that India will have the highest population in the world around in the years 2023-24. Nepal was 46th most populous country in the world in 1916. Comparatively slow growth rate caused its rank 48 in 2018. According to Census 2011, population of India was approximately 46 times more than the population of Nepal. Estimations show that presently India is 48 times bigger than Nepal on the basis of population and this ratio will be again 46 in 2030. Population of India and Nepal according as the Censuses 2001 and 2011, and some estimation for further years are presented in table 1.

Table 1. Population of India and Nepal in Absolute Numbers

\begin{tabular}{llllllll}
\hline Year & & 2001 & 2011 & 2015 & 2018 & 2030 & 2050 \\
\hline Population & India & 1028.73 & 1210.19 & 1314 & 1417.09 & 1512.98 & 1658.97 \\
(Million) & Nepal & 23.15 & 26.49 & 28 & 29.74 & 33.16 & 36.10 \\
\hline
\end{tabular}

To analyze the trend of population growth in India and Nepal, percentage growths were obtained on the basis of population of different years mentioned in table 2. Here, percentage of population growth of India and Nepal were $21.54 \%$ and $25.20 \%$ in the census year 2001 . Percentage of population growth of Nepal decreased in the years 2011, 2015 and 2018 in comparison to India and increased by approximately two times for the estimated population of 2030. Again, estimation shows that percentage of population growth of India will be slightly higher than Nepal in 2050.

Table 2. Population Growth of India and Nepal in Percentage

\begin{tabular}{|c|c|c|c|c|c|c|c|}
\hline Year & & 2001 & 2011 & 2015 & 2018 & 2030 & 2050 \\
\hline Population & India & 21.54 & 17.64 & 8.58 & 7.85 & 6.77 & 9.65 \\
\hline growth (\%) & Nepal & 25.20 & 14.44 & 5.68 & 6.21 & 11.50 & 8.87 \\
\hline
\end{tabular}




\section{Macrothink}

Line graph is effective means of presentation of data especially for comparison. Line graph (figure 1) clearly shows that percentage of population growth in India was rapidly decreased from 2001 to 2015; decrease slowly from 2015 to 2030 and comparatively it will increase in 2030 to 2050. Nature of percentage of population growth in Nepal was almost same as of India from 2001 to 2015 and slightly increased from 2015 to 2018. It will rapidly increase up to 2030 and then gradually decrease up to 2050 .

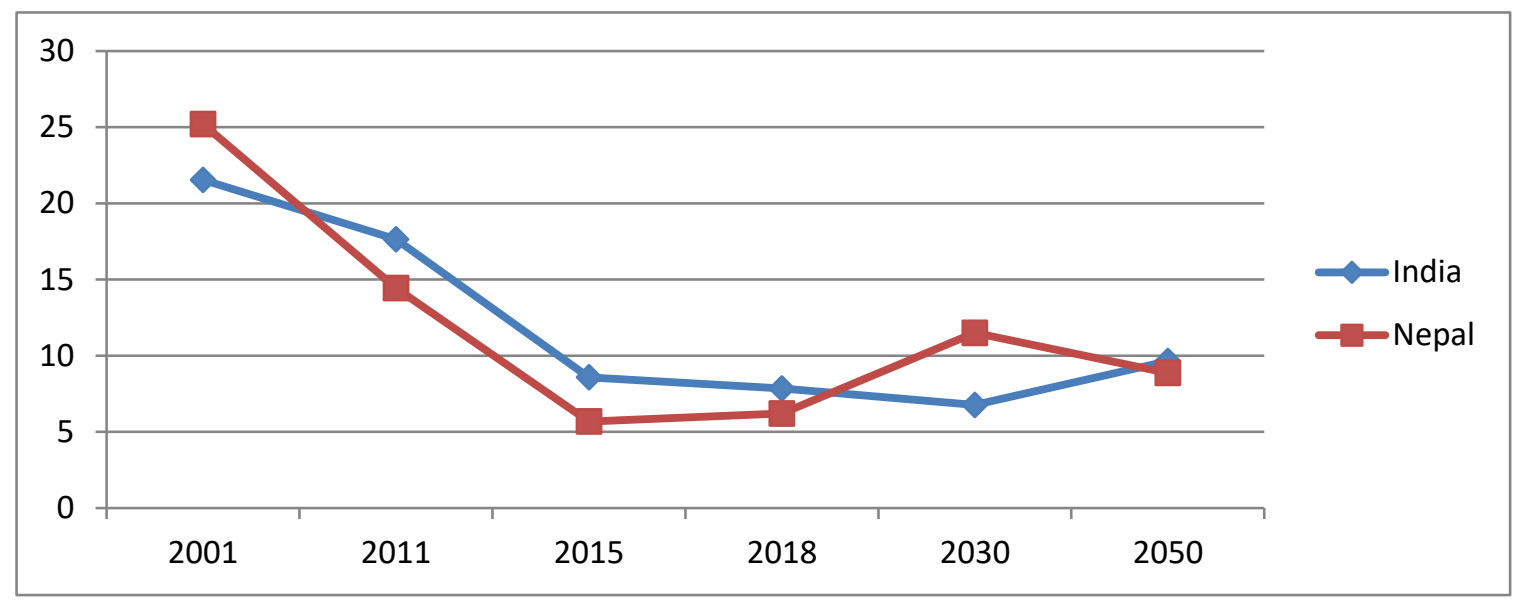

Figure 1. Percentage of Population Growth in India and Nepal

Enrollment of the children in respective grades/levels is one of the most important indicators to show the access of children in education.

Table 3. Enrollment in Primary Education of India and Nepal in Absolute Numbers

\begin{tabular}{llllll}
\hline Year & & $\mathbf{2 0 0 0 - 0 1}$ & $\mathbf{2 0 0 5 - 0 6}$ & $\mathbf{2 0 1 0 - 1 1}$ & $\mathbf{2 0 1 4 - 1 5}$ \\
\hline Enrollment & India & 113.80 & 132.10 & 135.3 & 130.50 \\
(Million) & Nepal & 3.85 & 4.50 & 4.95 & 4.34 \\
\hline
\end{tabular}

Table 3 shows that 113.80 million children were enrolled in primary education in India in the year 2000-01 while in Nepal, this number was 3.85 million in the same year. Enrollment number was gradually increased in both countries in the years 2005-06 and 2010-11 and coincidently decreased in both countries in the year 2014-15.

Table 4. Enrollment Growth of India and Nepal in Percentage

\begin{tabular}{lllll}
\hline Year & & $\mathbf{2 0 0 5 - 0 6}$ & $\mathbf{2 0 1 0 - 1 1}$ & $\mathbf{2 0 1 4 - 1 5}$ \\
\hline Enrollment & India & 16.08 & 2.42 & -3.55 \\
growth (\%) & Nepal & 16.79 & 10.02 & -12.44 \\
\hline
\end{tabular}


Comparing the percentage of enrollment growth (Table 4) in different years, Nepal had slightly high percentage $(0.71 \%)$ of enrollment growth in the years 2005-06 which increased by $7.6 \%$ in $2010-11$ and again decreased by $8.89 \%$ in the year $2014-15$. Negative percentages of enrollment growth indicate that absolute number of enrollment decreased in both the countries. Line graph (figure 2) further clarifies that percentage enrollment growth in India and Nepal decreased from 2005-06 to 2014-15. Decreased percentage of enrollment was far higher in Nepal than in India.

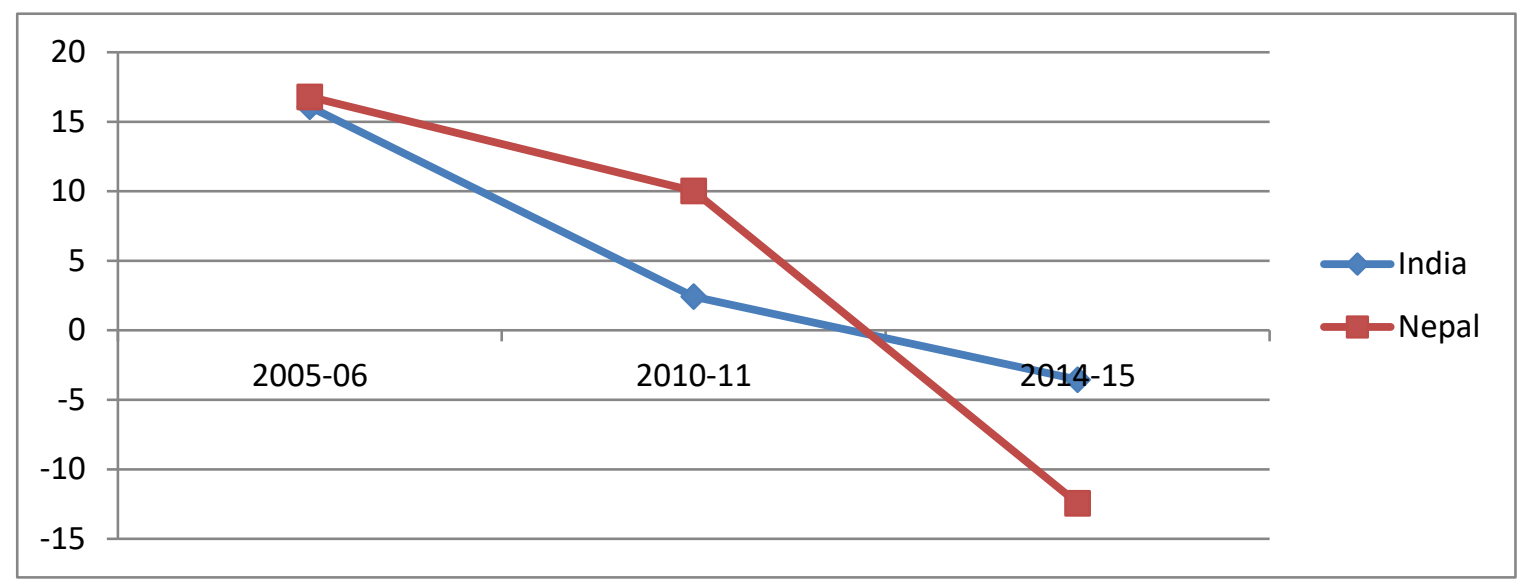

Figure 2. Trend of Percentage Enrollment Growth in India and Nepal

GER and NER are two educational indicators related to enrollment of the children. GER can't tell about the exact enrollment of children of specified age group for particular grade/level. It shows the actual percent of enrollment of the children of any age in any grade/level on the basis of total number of children of specified age group for that grade/level.

Table 5. Description of GER in Primary Education of India and Nepal

\begin{tabular}{lllllll}
\hline Year & & $\mathbf{2 0 0 0 - 0 1}$ & $\mathbf{2 0 0 5 - 0 6}$ & $\mathbf{2 0 1 0 - 1 1}$ & $\mathbf{2 0 1 3 - 1 4}$ & $\mathbf{2 0 1 4 - 1 5}$ \\
\hline GER (\%) & India & 95.7 & 109.4 & 116 & 101.4 & 100.1 \\
& Nepal & 124.7 & 138.8 & 121 & $130.1^{*}$ & 134.4 \\
\hline
\end{tabular}

* GER of 2012

The value of GER may be more or less or equal to 100 but the value of NER may not exceed the number 100. Its value may be less than or equal to 100 (maximum value). Table 5 shows that GER of primary education in India was $95.7 \%$ in the year $2000-01$ while this rate for Nepal was 124.7 in the same year. GER of Nepal in primary education was higher than India in the years 2005-06, 2010-11, 2013-14 and 2014-15. 
Table 6. Description of NER in Primary Education of India and Nepal

\begin{tabular}{llllll}
\hline Year & & $\mathbf{2 0 0 1}$ & $\mathbf{2 0 0 5 - 0 6}$ & $\mathbf{2 0 1 3 - 1 4}$ & $\mathbf{2 0 1 4 - 1 5}$ \\
\hline NER (\%) & India & & 84.5 & 88.08 & 87.4 \\
& Nepal & 81.1 & $87.4^{*}$ & $95.3^{* *}$ & 96.2 \\
\hline
\end{tabular}

* NER of $2004 * *$ NER of 2012

Real scenario of enrollment can be expressed by NER. NER of children tells that what percent of children of specified age group for any grade/level are enrolled in that grade/level and how many are out of schooling. Table 6 shows that NER gradually increased in Nepal in the years 2005-06, 2013-14 and 2014-15 but this rate slightly decreased in the year 2014-15 in India in comparison to the previous year. In India, NER $87.4 \%$ implies that $12.6 \%$ children of primary school age were out of school in the year 2014-15. Total population of age group 6-10 years (primary level) was 130.648 million in India in the year 2014. NER of this year shows that 16.461 million children of primary school age were not enrolled in the year 2014 . In Nepal, condition of NER was comparatively better than India during the period of last two decades. In the year 2014-15, value of NER 96.2\% indicates that in Nepal, 3.8\% children of primary school age had no access to primary education this year. Trend of population growth in Nepal indicates that the total population of children of age group 5-9 years (primary level) was 3.386 million in 2015 and NER shows that 128,705 children of primary school age were not enrolled in 2015.

Table 7. Description of Literacy Rates of India and Nepal

\begin{tabular}{|c|c|c|c|c|c|c|}
\hline Year & & 1971 & 1981 & 1991 & 2001 & 2011 \\
\hline Literacy & India & 34.5 & 43.6 & 52.3 & 64.8 & 73 \\
\hline rate $(\%)$ & Nepal & 13.9 & 23.3 & 39.6 & 53.74 & 65.94 \\
\hline
\end{tabular}

Literacy rate is another educational indicator, which shows the overall condition of right to education and access to education of a particular nation. In 1971, difference between literacy rates of India and Nepal was 20.6\% (Table 7). This difference of literacy rate gradually decreased in the years 1981, 1991, 2001 and became $7.06 \%$ in the year 2011. Difference of literacy rates of India in each decade from 1971 to 2011 was $9.1 \%, 8.7 \%, 12.5 \%$ and $8.2 \%$. This difference for same decades in Nepal was $9.4 \%, 16.3 \%, 14.14 \%$ and $12.2 \%$. Comparatively, progress in literacy rate of Nepal was higher than in India but overall literacy rate of India was higher by $7.06 \%$ than in Nepal in the year 2011 .

\section{Conclusion}

In present, most of the countries in the world have constitutional provisions for right to 
education. India and Nepal are both South Asian and close neighboring countries. Both countries have special and unique similarities in culture, religion, language, beliefs and values, and many other things. Both countries are members of UNO and signatories to almost all conferences under UNO and its alliance bodies. India and Nepal have now clear constitutional provisions for right to free and compulsory basic education.

These two countries are ancient countries and practicing democratic politics being free and independent in the decade of fifties of twentieth century. Both countries had made commitments to Karachi conference (1959) for free and compulsory primary education within a maximum period of 20 years, Jomtien conference (1990) for Education for All (EFA), Millennium Development Goals (MDGs) (2000) for making education accessible to all by the end of 2015, and many others.

Although India and Nepal both countries had made significant progress in the field of education but they have been unable to achieve the goals of EFA and MDGs. After the seven decades of Universal Declaration of Human Rights, the large population of India and Nepal is still illiterate. India and Nepal rank 2 and 48 occupying approximately $17 \%$ and $0.39 \%$ of the world population respectively. In India, 16.461 million primary school age children were not enrolled in 2014. In the same year, dropout rate in primary education was $4.34 \%$ which implies that 5.67 million students left the school without completing the primary education. Thus, around the completion of duration of MDGs (2015) 22.131 million children were unable to get/complete primary education in India.

Similarly, in Nepal, 128705 children of primary school age had no access to primary education in 2015. Dropout rate 4.2\% of primary education in 2014-15 indicates that 142253 students did not complete primary education that year. Total number of out of school children and dropout students in the year 2015 was 270 958. Finally, it can be concluded that after 1950s, India and Nepal both countries made so many policies to make easy access to education. Clear constitutional provisions for right to free and compulsory basic education are also made in both countries. Other programs like non-formal education, distance education and open schooling are being also implemented in both countries to enhance access to education and hence increase literacy rates. Despite these efforts, both countries are still unable to fulfill the international commitments and achieve expected educational goals. Results show that there is huge gap between educational policies and practices in both countries. Concern authorities of both countries need to identify the weaknesses in the implementation of constitutional provisions for right to education and causes of gap between policy and practice so that related policies can be reformed and practiced in the ground.

\section{Funding}

This research did not receive any specific grant from funding agencies in the public, commercial, or not-for-profit sectors. 


\section{Conflict of interest}

There is no conflict of interest.

\section{References}

Ahmad, T. (2016). Constitutional Right to an Education in Selected Countries, India. The Law Library of Congress, Global Legal Research Centre.

Bhandari, S. (2014). Self-Determination and Constitution Making in Nepal. Springer.

Cheney, G. R. (2005). India Education Profile. National Center on Education and the Economy. $\quad$ Retrieved from http://www.ncee.org/wp-content/uploads/2010/04/India-Education-Report.pdf

Constitution of the Kingdom of Nepal. (1990). Himalayan, the Journal of the Association for Nepal and Himalayan Studies, 11(1), 19-68.

Dahal, G. (2017). Constitution of Nepal and Political Development: Adaptation and Challenges of Implication. Janapriya Journal of Interdisciplinary Studies, 6, 148-159. https://doi.org/10.3126/jjis.v6i0.19316

Dahal, H. (2015). Education Beyond 2015. Kathmandu: National Campaign for Education (NCE-Nepal).

Dahal, R. K. (2001). Constitutional and Political Developments in Nepal. Kathmandu: Ratna Pustak Bhandar.

Demographic Trends of India. (n. d.). Retrieved form http://shodhganga.inflibnet.ac.in/bitstream/10603/147711/16/12_chapter4.pdf

Devkota, S. P., \& Bagale, S. (2015). Primary Education and Dropout in Nepal. Journal of Education and Practice, 6(4), 153-157.

G. C., R. K., \& Shrestha, N. L. (2014). Literacy and Educational Status of Nepalese Population. Population Monograph of Nepal Volume II. Kathmandu: Central Bureau of Statics.

Government of India. (2014). Education for All towards Quality with Equity India. New Delhi: National University of Educational Planning and Administration.

Government of India. (2016). Educational Statistics at a Glance. New Delhi: Ministry of Human Resource Development Department of School Education and Literacy.

Government of India. (2017). Youth in India. New Delhi: Ministry of Statistics and Programme Implementation.

Government of Nepal Act. (1948). Retrieved from http://www.lawcommission.gov.np/en/wp-content/uploads/2018/09/government-of-nepal -act-2004-1948.pdf 
Government of Nepal. (2014). Population Monograph of Nepal Volume II. Kathmandu: Central Bureau of Statistics.

Government of Nepal. (2016). Fourteenth Plan (Fiscal Year 2016-2019). Kathmandu: National Planning Commission.

Heymann, J., Raub, A., \& Cassola, A. (2014). Constitutional rights to education and their relationship to national policy and school enrolment. International Journal of Educational Development, 39, 131-141. https://doi.org/10.1016/j.ijedudev.2014.08.005

Juneja, N. (2003). Constitutional Amendment to Make Education a Fundamental Right, Issues for a Follow-up Legislation. New Delhi: National Institute of Education planning and Administration.

Mathema, K. B. (2007). Crisis in education and future challenges for Nepal. European Bulletin of Himalayan Research, 31, 46-66.

MHRD. (2008). the Right of Children to Free and Compulsory Education Bill, 2008. Retrieved from http://nuepa.org/Download/rightfreeeducation\%20bill.pdf

Ministry of Education (MoE), United Nations Children's Fund (UNICEF) and United Nations Educational, Scientific and Cultural Organization (UNESCO). (2016). Global Initiative on Out of School Children-Nepal Country Study. Kathmandu, Nepal: UNICEF.

Ministry of Education. (2015 a). Nepal Education in Figures 2015. At-A-Glance. Kathmandu: Author.

Ministry of Education. (2015 b). Education for All National Review Report 2001-2015. Kathmandu: UNESCO.

Ministry of Human Resource Development. (2016). National Policy on Education 2016 Report of the Committee for Evaluation of the New Education Policy. New Delhi: Government Publication.

Mondal, A. (2014). Free and Compulsory Primary Education in India under the British Raj: A Tale of an Unfulfilled Dream. SAGE Open, July-September, 1-12.

National Coalition for Education and World Vision India. (2012). Joint Report India, 13th Session. Retrieved from http://lib.ohchr.org/HRBodies/UPR/Documents/session13/IN/JS6_UPR_IND_S13_2012 _JointSubmission6_E.pdf

National Education Commission. (1992). Report of the National Education Commission (Executive Summary). Kathmandu: Ministry of Education.

National Education System Plan for 1971-76. (1971). Report of the National Education System Plan. Kathmandu: Ministry of Education, His Majesty's Government of Nepal.

National Planning Commission. (2017). Periodic Plans. Retrieved from www.npc.gov.np/en/category/periodic_plans 
Nepal's Constitution of 2015 with Amendments through 2016. (2016). Constituteproject.org Retrieved from https://www.constituteproject.org/constitution/Nepal_2016.pdf?lang=en

Parajuli, M. N., \& Acharya, S. (2014). Free and Compulsory Education in Federal Nepal. A Resource Material on Education and Federalism in Nepal. Lalitpur, Nepal: Asaman Nepal.

Population Education and Health Research Center (P) Ltd. (2016). Nepal Population Report 2016 Submitted to Government of Nepal, Ministry of Population \& Environment.

Population Reference Bureau. (2016). 2016 World Population Data Sheet with a Special Focus on Human Needs and Sustainable Resources. Retrieved from https://assets.prb.org/pdf16/prb-wpds2016-web-2016.pdf

Sharma, B. R. (n. d.). Short Notice on National Population Census of Nepal. Retrieved from https://unstats.un.org/unsd/demographic/meetings/wshops/Thailand_15Sept08/docs/Sessi on03_CensusPreparation_Short-Notices/ShortNotice_Nepal.pdf

The Constitution of India. (1949). Retrieved from https://www.india.gov.in/sites/upload_files/npi/files/coi_part_full.pdf

The Gazette of India Extraordinary. (2009). the Right of Children to Free and Compulsory Education Act, 2009. Retrieved from http://eoc.du.ac.in/RTE\%20-\%20notified.pdf

The Interim Constitution of Nepal. (2007). Retrieved from http://www.constitutionnet.org/sites/default/files/interim_constitution_of_nepal_2007_as _amended_by_first_second_and_third_amendments.pdf

Timalsina, T. P., \& Shreshtha, M. K. (2005). Constitution of Nepal (A brief comment) (In Nepali). Kathmandu: Swadesh Publication.

Tuladhar, S. K. (2004). The out-of-school children's programme in Nepal: an analysis. Paris: International Institute for Educational Planning.

UN. (1945). Universal Declaration of Human Rights. Retrieved from http://www.un.org/en/udhrbook/pdf/udhr_booklet_en_web.pdf

UN. (1959). Declaration of the Rights of the Child. Retrieved from http://www.childlineindia.org.in/pdf/Declaration\%20of\%20the\%20Rights\%20of\%20the \%20Child-1959.pdf

UN. (1989). Convention on the Rights of the Child. Retrieved from http://www.ohchr.org/Documents/ProfessionalInterest/crc.pdf

UNESCO Institute for Statics. (2005). Children Out of School Measuring Exclusion from Primary Education. Montreal, Canada: UNESCO Institute for Statics.

UNESCO world education report. (2000). The Right to Education: towards education for all throughout life. Retrieved from http://unesdoc.unesco.org/images/0011/001197/119720e.pdf 
UNESCO. (1968). International Conference on Educational Planning; A survey of problems and prospects. Retrieved from http://unesdoc.unesco.org/images/0008/000857/085719eo.pdf

UNESCO. (2007). A Human Right-Based Approach to Education for All. Retrieved from http://unesdoc.unesco.org/images/0015/001548/154861e.pdf

United Nations, Department of Economics and Social Affairs, Population Division. (2017). World Population Prospects: The 2017 Revision, DVD Edition.

Wagle, D. (2012). Dropout of Children from Schools in Nepal. Unpublished M. Phil. Thesis. Norwegian University of Science and Technology.

World Declaration on Education for All Meeting Basic Learning Needs. (1990). Retrieved from http://ncpcr.gov.in/showfile.php?lid=124

World Development Indicators database, World Bank. (2018). Population 2017. Retrieved from http://databank.worldbank.org/data/download/POP.pdf

\section{Copyright Disclaimer}

Copyright for this article is retained by the author(s), with first publication rights granted to the journal.

This is an open-access article distributed under the terms and conditions of the Creative Commons Attribution license (http://creativecommons.org/licenses/by/3.0/). 